\title{
Article \\ Adaptation Strategies for Flooding Risk from Rainfall Events in Southeast Spain: Case Studies from the Bajo Segura, Alicante
}

\author{
Esther Sánchez-Almodóvar ${ }^{1, *(\mathbb{D})}$, Jorge Olcina-Cantos ${ }^{2}\left[\right.$ and Javier Martí-Talavera ${ }^{3}[0$ \\ 1 Water and Territory Research Group, Interuniversity Institute of Geography, University of Alicante, \\ 03690 San Vicente del Raspeig, Spain \\ 2 Laboratory of Climatology, Department of Regional Geographic Analysis and Physical Geography, \\ University of Alicante, 03690 San Vicente del Raspeig, Spain; jorge.olcina@ua.es \\ 3 Laboratory of Climatology, Interuniversity Institute of Geography, University of Alicante, \\ 03690 San Vicente del Raspeig, Spain; jmt25@alu.ua.es \\ * Correspondence: esther.sanchez@ua.es
}

check for

updates

Citation: Sánchez-Almodóvar, E.; Olcina-Cantos, J.; Martí-Talavera, J. Adaptation Strategies for Flooding Risk from Rainfall Events in Southeast Spain: Case Studies from the Bajo Segura, Alicante. Water 2022, 14, 146. https://doi.org/10.3390/ w14020146

Academic Editors: Joaquin Melgarejo and Patricia Fernández-Aracil

Received: 1 December 2021

Accepted: 1 January 2022

Published: 7 January 2022

Publisher's Note: MDPI stays neutral with regard to jurisdictional claims in published maps and institutional affiliations.

Copyright: (c) 2022 by the authors. Licensee MDPI, Basel, Switzerland. This article is an open access article distributed under the terms and conditions of the Creative Commons Attribution (CC BY) license (https:/ / creativecommons.org/licenses/by/ $4.0 /)$.

\begin{abstract}
The management of runoff during torrential rainfall events is a significant problem in urban areas of southeast Spain. The increase in soil sealing and the occupation of areas prone to flooding have aggravated this problem. Due to this situation, municipal administrations, in collaboration with the concession holder for the supply of water and sewage services, Hidraqua Gestión Integral de Aguas de Levante SA, are committed a more efficient management of non-conventional water resources. An example of this can be found in the municipalities of Rojales, Daya Nueva, and San Fulgencio. These towns are located in the Bajo Segura region of the province of Alicante, where various initiatives have been implemented that break away from the traditional paradigm of rigid infrastructures. These initiatives include green spaces or areas, and sustainable urban drainage systems (SUDS) or nature-based solutions (NBS). This article presents various case studies. Firstly, in the town of Rojales, where several actions are being undertaken to improve the management of wastewater and rainwater and provide a solution to unauthorised dumping, as well as encouraging the use of reclaimed water with the creation of a recreational green area, El Recorral Park. Secondly, in the case of Daya Nueva, the Europa Park constitutes a recreational green area, Europa Park, facilitates runoff drainage by SUDS and NBS. Finally, the creation of a floodable pond in the municipality of San Fulgencio encourages the use of wastewater, thus avoiding the discharge of this non-conventional water resource into the sea. In addition, the pond facilitates the appropriate management of runoff water. The working method in this article has been twofold: firstly, bibliographical references have been consulted from other national and international areas; and secondly, the technical projects in the case studies have been analysed in detail. Several field trips have been made to the selected municipalities, accompanied by the technical personnel in charge of the execution of the projects, to examine the measures adopted. The results show that the implementation of these systems contributes to adapting to climate change and creates more resilient urban spaces.
\end{abstract}

Keywords: urban runoff; water management; climate change

\section{Introduction}

In the current context of climate change, the problem of managing urban runoff is increasingly important in the western Mediterranean basin, where the effect of global warming has a direct impact on the increase in atmospheric extremes, as reveal by studies that show an increase in the number of rainstorms and an increase in the intensity of rainfall [1-6]. This change in rainfall patterns is one of the causes of the flooding of urban environments and the collapse of sewage and stormwater drainage systems [7]. Given the warming climate, rainwater harvesting has become an essential action for territories with scarce natural water resources. The need for water and land planning under the assumptions of the circular economy and within the framework of the Sustainable Development 
Goals (hereinafter SDGs), makes rainwater management a key development action for the decades ahead.

Floods are the most common natural hazard events worldwide, as well as the event that causes the greatest loss of life and economic loss [8] (p. 5). The frequency and intensity of floods for the period 1900-2015 have increased the number of people affected and the amount of material damage. This is mainly due to the urbanisation and occupation of the affected areas [9] (p. 915). This dynamic also can be seen in the Mediterranean region and especially in southeast Spain, where the increased exposure and vulnerability of the population [10] has resulted in the creation of new risk areas [11]. According to a study by Gil-Guirao et al. [12], 3608 floods occurred on the Spanish Mediterranean coast during the period 1960-2019.

A European Spatial Planning Observation Network (ESPON) report states that flooding has become an increasing problem for built-up environments and points to the consequences of increased soil sealing, which leads to an increased risk of flooding, as natural retention in the soil through infiltration is greatly reduced [13] (p. 33). The effects of urban growth and the increasing impact of climate change on urban areas have had a major impact on stormwater drainage, resulting in the inability of the sewage system to drain large volumes of urban runoff [14]. This problem is aggravated when urban runoff pollutes the receiving seas, streams, rivers, lakes and ponds [15].

The management of conventional drainage systems has been a constant challenge facing cities during the last century. Most sewage systems are unitary systems (combining sewage and storm) and their design did not consider the expansion of urban areas, the loss of vegetation cover, and the effects of climate change [16]. This is especially evident in the highly populated coastal areas of the eastern Iberian Peninsula, which are frequently affected by heavy rainfall [17].

In Spain, a new approach led by the New Water Culture Foundation (FNCA, Fundación Nueva Cultura del Agua), appeared in the 1990s and focused on non-conventional sources such as purification, desalination and rainwater [18], as regulated by European Directive 91/271 and the national regulatory framework on environmental quality and urban drainage (Royal Decree 1290/2012). Within the framework of European directives, the Water Framework Directive 2000/60/EC of the European Parliament and Council includes among its objectives that water protection "helps mitigate the effects of flooding" [19] (p. 5). Traditional stormwater management has captured runoff through combined sewer systems and channelled it to wastewater treatment plants (WTPs) or water bodies [20]. However, in recent years this approach has been changing with the implementation of nature-based solutions (NBS) and sustainable urban drainage systems (SUDS) which model the natural water cycle, reduce surface runoff levels, and so improve water quality [16]. To this effect, Directive 2007/60/EC of the European Parliament and of the Council of 23 October 2007 on the assessment and management of flood risks was specifically developed. This directive was transposed into Spanish legislation by Royal Decree 903/2010 of 9 July 2010 on the assessment and management of flood risks [21]. Royal Decree 638/2016, of 9 December, amended the Public Water Domain Regulations, and helped bring about a change in thinking in the pattern of urban drainage in Spain - with a migration from the conventional approach towards nature-based solutions [22].

In Spain, SUDS have experienced a significant boost in recent years because of: (a) the development of major and extreme rainfall events (2015, 2017, 2019 and 2020) on the Mediterranean coast, with a great hourly intensity of rainfall that evidences the local effects of global warming [5]; (b) the poor adaptation of urban environments to this type of increasingly frequent rainfall, with sewage systems that lack specific collectors for rainwater and the capacity to evacuate heavy rainfall, and; (c) the implementation of European initiatives, with significant financial aid for territorial adaptation to climate change; (d) the publication of an official manual for the construction of infrastructure that complies with European and Spanish regulations-especially with regard to the use of stored water [23]; and (e) the development of strategies for the development of green 
infrastructure in Europe and Spain. All these factors have favoured the development of sustainable drainage actions and the construction of 470 storm reservoirs throughout Spain [24], a quarter of which are in the southeast (in the provinces of Alicante, Murcia and Almeria), in a variety of types and sizes [25].

Under the common premise of analysing local water-efficient and sustainable solutions for reducing the risk of water extremes, various studies have analysed these systems: (a) according to their type: rainwater collectors, tanks and flood parks [26-30]; (b) according to their purpose in urban areas: water reuse, reduction of urban runoff [31-34]; and (c) according to the "philosophy" of their structural conception: hard infrastructure works, soft works, mixed works [35,36].

This research focuses on the types of actions conducted in municipalities in the Bajo Segura area that improve the management of rainwater runoff and mitigate the risk of flooding. It also highlights the use of non-conventional water resources (treated water and rainwater) in view of the recent change of thinking in the planning and integrated management of water resources. Among the structural and non-structural measures analysed in the case studies, NBS and SUDS stand out as soft measures that mitigate the problems created by urbanisation, such as interception, evapotranspiration, infiltration and the sealing of urban runoff [37]. These systems have been shown to be effective in various locations along the Mediterranean coast and reflect a commitment to sustainability and territorial planning.

These actions assume even greater value, if possible, after the torrential rains of September 2019 that affected the entire Bajo Segura area. Local administrations are now committed to measures that mitigate the effects of torrential rains. The Vega Renhace Plan [38] is in line with this aim and combines hard and soft sustainable measures to help mitigate urban flooding and create more resilient territories. These initiatives are taking centre stage in local administrations and the entities responsible for managing water resources-Hidraqua Gestión Integral de Aguas de Levante SA in this case [39]. At the European level, the province of Alicante is a "Living Lab" within the European B-WaterSmart project, which aims to define strategies for efficient and intelligent water management, the reduction of consumption and greater water sustainability [40].

The aims of this research are: (a) analyse recent actions in municipalities in the Bajo Segura area to improve runoff management; (b) highlight the implementation of nature-based solutions (NBS) and sustainable urban drainage systems (SUDS) as potential measures to mitigate the impact of runoff and control its quantity and quality; (c) assess the efficiency of implemented actions; and (d) promote NBS and SUDS as efficient measures for sustainably managing runoff and climate change in compliance with the sustainable development goals.

\section{Study Area}

The municipalities under study, Rojales, Daya Nueva and San Fulgencio, are in the southeast of Spain, in the Bajo Segura or Vega Baja area of the southernmost part of the province of Alicante (Figure 1). According to the database of the National Geographic Institute (IGN), referring to the Geographic Nomenclature of Municipalities and Population Entities, these municipalities occupy a total area of $54.52 \mathrm{~km}^{2}$ (Rojales occupying $27.6 \mathrm{~km}^{2}$, Daya Nueva occupying $7.09 \mathrm{~km}^{2}$, and San Fulgencio occupying $19.75 \mathrm{~km}^{2}$ ). [41]. The original nucleus of Rojales is on the fluvial deposits of the River Segura, while Daya Nueva and San Fulgencio are just two kilometres north of this river. These municipalities underwent a great social, territorial and economic transformation from the 1950s and 1960s. Socio-economic development was accompanied by a boom in tourism and the property sector, which boosted the phenomenon known, from the 1970s onwards, as "residential tourism" [42]. This process changed the urban model and caused intense territorial transformations in the study area. There was further acceleration in this process from the 1980s onwards, especially in the case of Rojales and San Fulgencio. As of the Urban Real Estate Land Registry Statistics for the year 2020, provided by the Ministry of Finance, 
reveal the age of the properties in the study area [43]. This source shows how that $50.5 \%$ of the properties in Rojales were built between 2000 and 2010. The urban expansion of this municipality has been towards the south, between the mountainous elevation of La Atalaya and the La Mata Salt Lagoon, where numerous residential estates have been built. Nearly $47 \%$ of properties in San Fulgencio were built in the same decade and this development did not take place near the original nucleus, but two kilometres to the north-east of the town centre in the hills of the Sierra del Molar. Daya Nueva also had its own urban expansion during the same decade, but at a more moderate pace, with around $40 \%$ of the properties in the municipality being built during this decade. It is worth noting that in Rojales and San Fulgencio, urban expansion took place in hilly areas, and in the case of San Fulgencio, the flat farmlands have remained undeveloped. The augment in urbanisation has led to a great increase in the impervious surface area or soil sealing, as well as a major territorial transformation that led to the levelling and occupation of steep slopes, such as La Atalaya (Rojales) and the Sierra del Molar (San Fulgencio), and this is causing serious problems for runoff management.
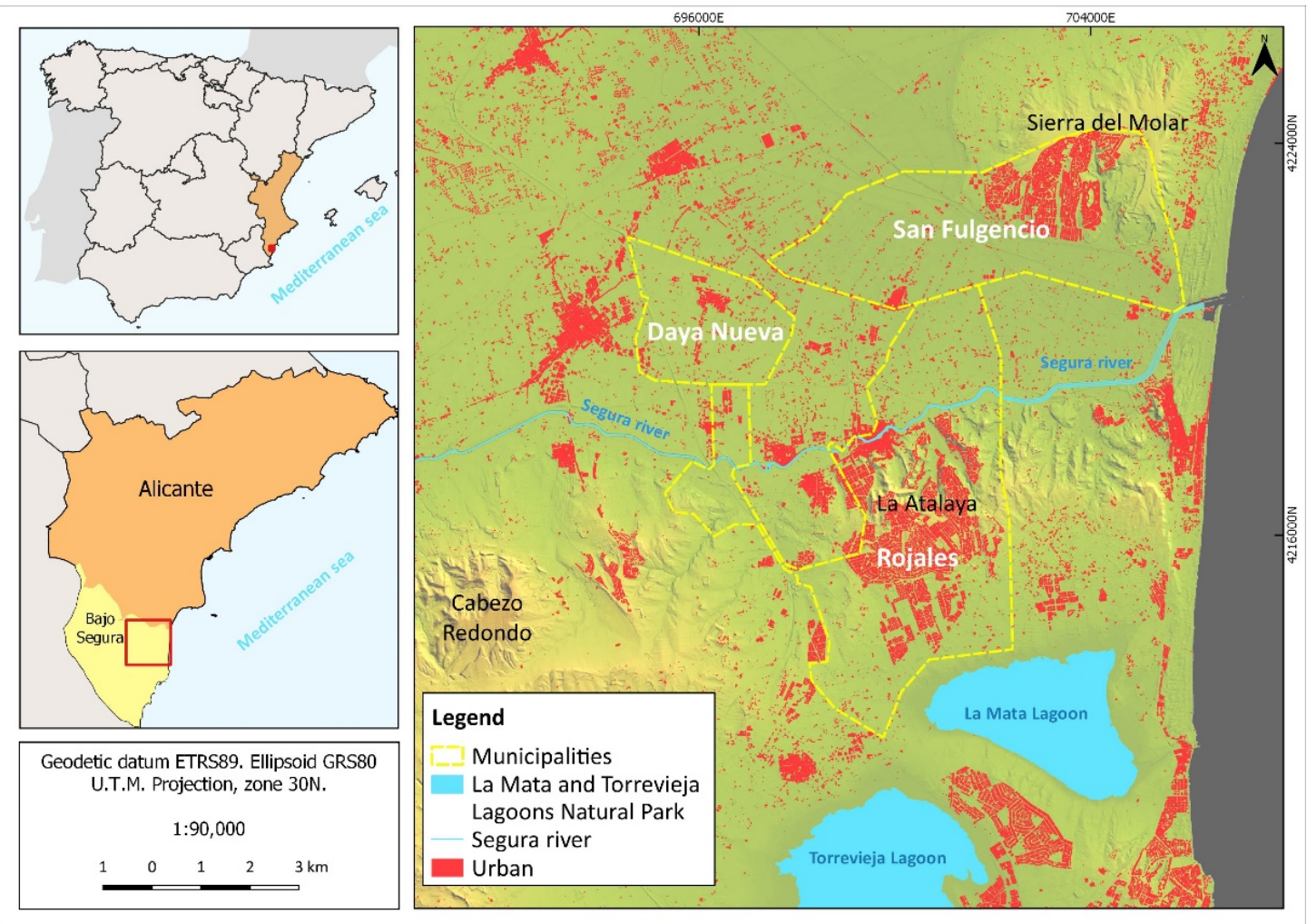

Figure 1. Location of the cases studied. Source: Instituto Cartográfico Valenciano (ICV). Own elaboration.

\section{Methodology}

The method used for the development of this work was twofold: consultation of bibliographical references in other national and international areas; and fieldwork in the study area, which included interviews with specialists in charge of water management in the municipalities concerned. The bibliographic search to establish the theoretical bases. Various official databases were managed to describe the study area. For the knowledge of the physical characteristics of the municipalities, the database of the National Geographic Institute was accessed, specifically to the Geographic Nomenclature of Municipalities and Population Entities, which contains the municipal surface areas. In the analysis of urban dynamics, the Urban Real Estate Cadastre Statistics database of the Ministry of Finance was used to identify the age of buildings in each of the case studies. To analyse the various case studies, a detailed review of the technical projects in each of the actions was made and this included several field trips to the municipalities to examine the measures adopted. 
Interviews were held in September and November 2020 with specialists from the town councils and the water and sewage concessionary company, Hidraqua Gestión Integral de Aguas de Levante SA. Qualitative information was collected on the measures implemented for runoff management (Table 1), the advantages and disadvantages, as well as projects or ideas for the future. The interviews were completed with a visit to El Recorral Forest Park and Lo Pepín and Doña Pepa wastewater treatment plants in Rojales. Europa Park was visited in the municipality of Daya Nueva, as well as a floodable pond next to the municipal sports area in San Fulgencio.

Table 1. Flood risk adaptation measures implemented in the case studies.

\begin{tabular}{cccc}
\hline Measure & Location & Construction Date & Management \\
\cline { 1 - 2 } El Recorral Park & Rojales & May 2019 & \\
\cline { 1 - 2 } $\begin{array}{c}\text { Remodelling of Lo } \\
\text { Pepín WWTP }\end{array}$ & Rojales & November 2019 & $\begin{array}{c}\text { Hidraqua Gestión } \\
\text { Integral de Aguas de } \\
\text { Levante SA }\end{array}$ \\
\cline { 1 - 2 } $\begin{array}{c}\text { Combined sewer } \\
\text { system storm overflow } \\
\text { tank Doña Pepa }\end{array}$ & Rojales & January 2021 & \\
\cline { 1 - 2 } Europa Park & Daya Nueva & November 2020 & \\
\cline { 1 - 2 } Floodable Pond & San Fulgencio & December 2019 & \\
Source: Hidraqua Gestión Integral de Aguas de Levante SA. Own elaboration.
\end{tabular}

\section{Results}

\subsection{Rojales}

The wastewater treatment system in Rojales consists of five treatment plants (Figure 2): Rojales Casco, to the north, is currently operated by the Global Omnium Medio Ambiente; and four treatment plants to the south are operated by Hidraqua Gestión Integral de Aguas de Levante SA: Ciudad Quesada I and II, Lo Pepín and Doña Pepa. The current Lo Pepín plant is an integration of the old Lo Pepín I WWTP (always active) and Lo Pepín II (out of service following its installation in 2008 until remodelling and refurbishment in 2016), while the Doña Pepa WWTP currently operates as a combined sewer system storm overflow tank [44].

Wastewater treatment has faced constant difficulties in recent years due to the refusal to authorise discharges from the four treatment plants on the southern side of the municipality. This situation has led to several disciplinary proceedings by the River Segura Management Authority and fines were issued to the local administrations. The main problem occurred at the Lo Pepín and Doña Pepa WWTPs, in the southernmost part of the municipality (at an altitude of 24 and 11 metres, respectively). During rainstorms, sewage flows by gravity towards both treatment plants. In addition, the southern part of the municipality has a north-south inclination that generates large volumes of surface runoff that flows downhill towards the La Mata and Torrevieja Lagoons Nature Park. Storm flows of wastewater and rainwater exceeded the design of both facilities, causing the discharge of untreated water into a network of irrigation channels that eventually reach La Mata and Torrevieja Lagoons (declared a "sensitive area" by the Secretary of State for Water and Coasts on 25 May 1998) [45]. Faced with this problem, Rojales Town Council, in collaboration with Hidraqua, implemented the measures described below to improve the management of wastewater and rainwater, as well as to encourage the use of reclaimed water.

Firstly, the Lo Pepín II WWTP was adapted to allow a shared distribution of flows within the current Lo Pepín WWTP (see Figure 3). This action enabled a correct biological treatment, using activated sludge with nitrogen elimination to improve the quality of the effluent, while extending tertiary treatment [44] to meet the 2.1 quality standards set out in Royal Decree 1620/2007 that regulates the reuse of treated wastewater [46]. 


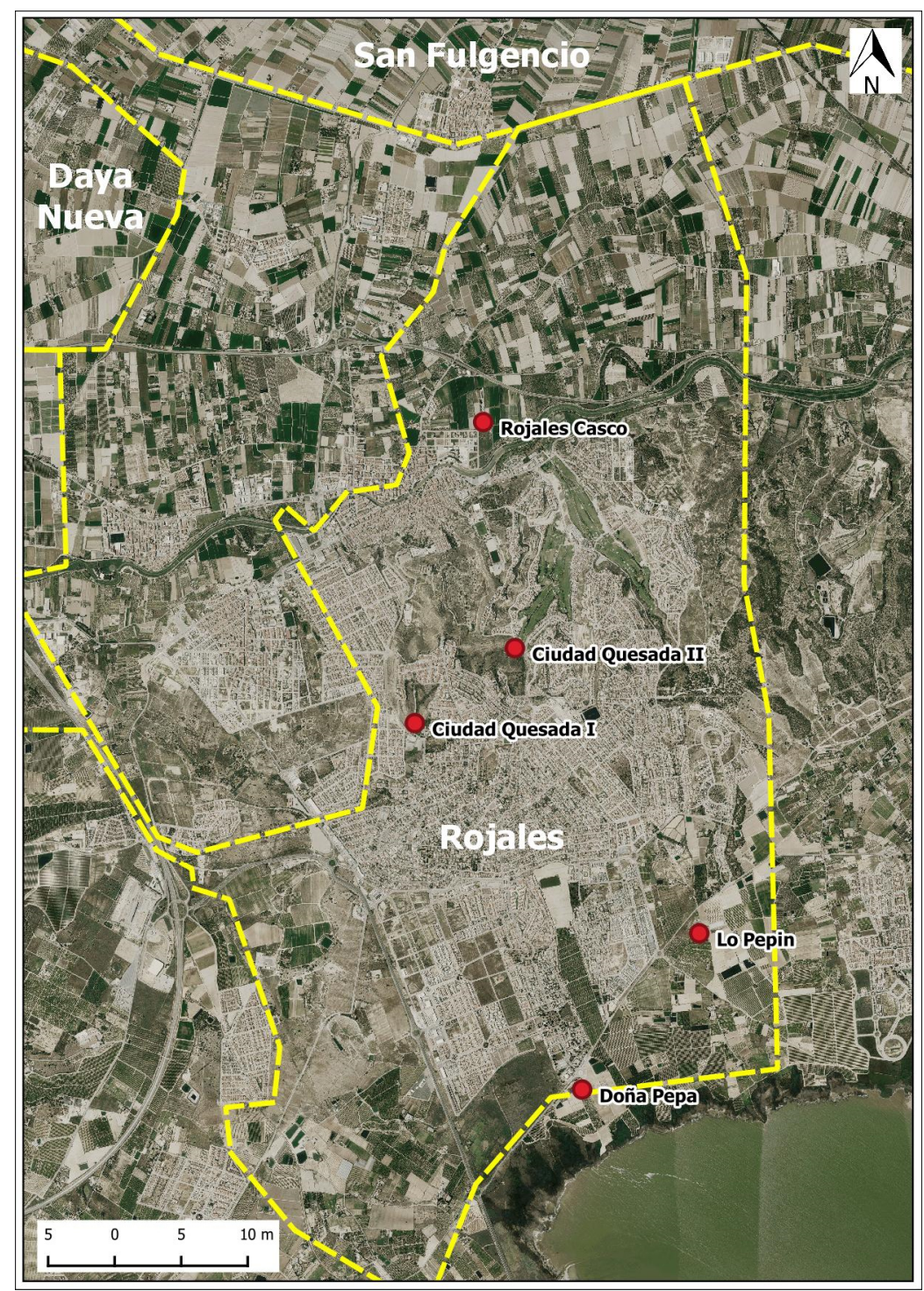

Figure 2. Location of the treatment plants in Rojales. Source: Instituto Cartográfico Valenciano (ICV). Own elaboration.

Secondly, to capture the initial flows of highly polluted wastewater and rainwater, a combined sewer system storm overflow tank was built in the entrance to Lo Pepín WWTP [44]. The installation of this type of tank is one of the most efficient measures for wastewater and rainwater management at treatment plants in the event of heavy rainstorms. In this case, an underground combined sewer system storm overflow tank was built with a usable storage volume of $1200 \mathrm{~m}^{3}$. The main objective was to prevent the release of untreated flows into the La Mata and Torrevieja Lagoons Nature Park. The tank also prevents discharges of raw sewage into the irrigation network and/or the natural ecosystem in case of a plant breakdown.

Remodelling the Lo Pepín WWTP and increasing its treatment capacity resulted in the Doña Pepa WWTP losing functionality due to its reduced capacity and lack of an authorised discharge point. To increase the workability of the existing facilities, wastewater treatment was centralised at the Lo Pepín WWTP and the Doña Pepa WWTP was transformed into a combined sewer system storm overflow tank with a usable capacity of $1200 \mathrm{~m}^{3}$ [44] (Figure 4). The main function of the Doña Pepa tank is to collect the flows from the residential estates in Pueblo Bravo and Doña Pepa through a gravity spillway at the Lo Pepín WWTP. These flows are stored in the storm overflow tank and pumped to the Lo Pepín WWTP for treatment after a storm has passed. During heavy rainfalls, once the Doña 
Pepa storm overflow tank is full, the flows are released with an elevated level of dilution so as not to damage the receiving environment. The storm overflow tanks (Lo Pepín and Doña Pepa) allow the collection of peak storm flows for subsequent treatment at the Lo Pepín WWTP.

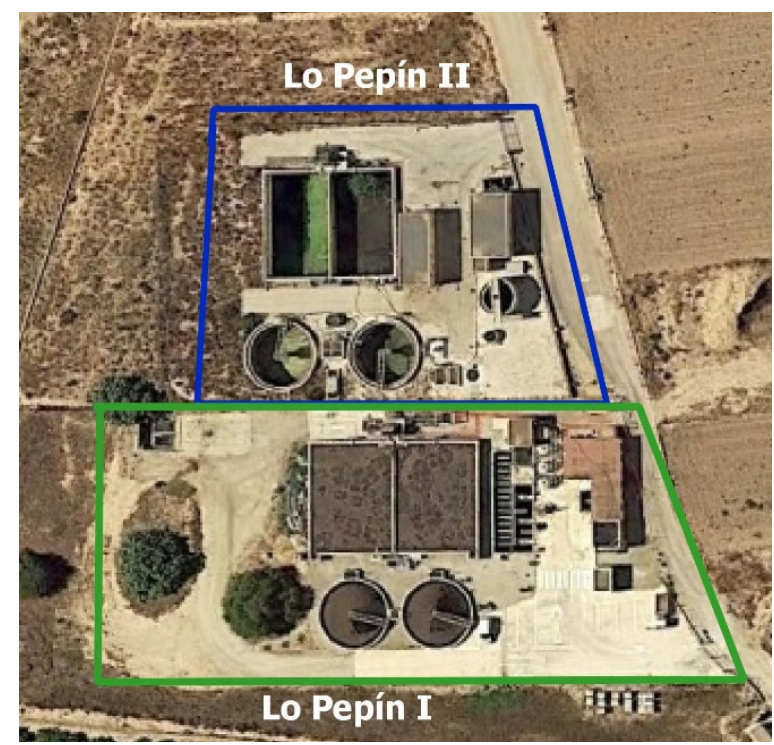

(a)

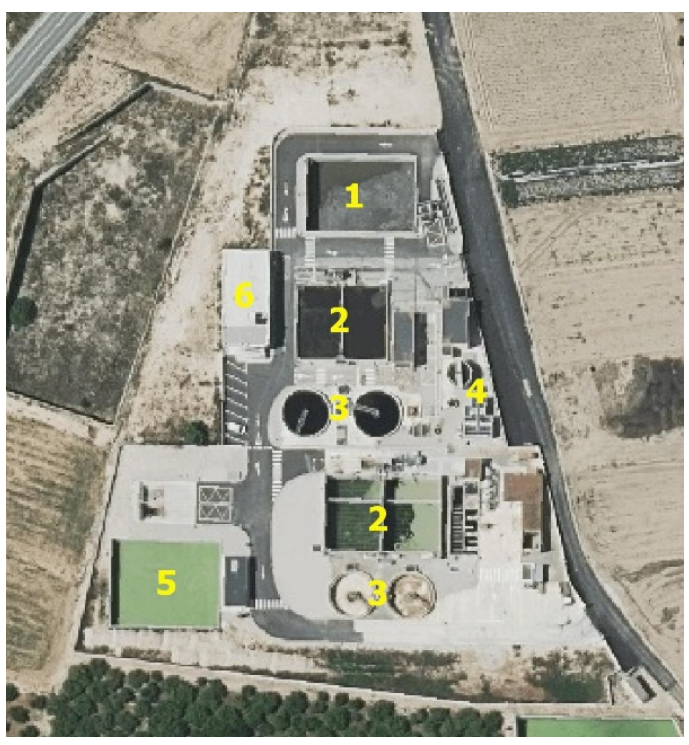

(b)

Figure 3. (a) Lo Pepín I and II WWTP before adaptation and integration; (b) Lo Pepín WWTP after integration. Key: Purification process. (1) Anti-SWWW tank, (2) biological aeration, (3) clarification, (4) tertiary treatment, (5) reclaimed water tank, (6) control building. Source: (a) Google Earth (7 June 2018); (b) ICV (2020) (11 August 2020). Own elaboration.

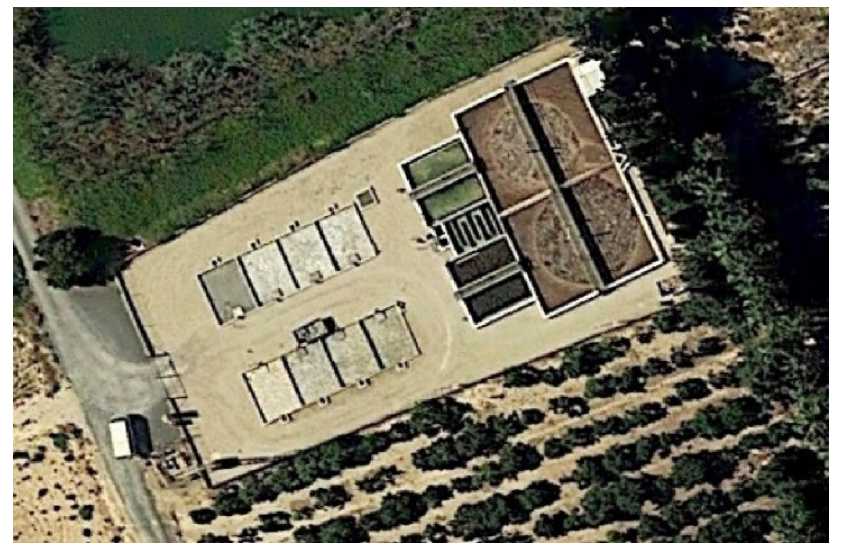

(a)

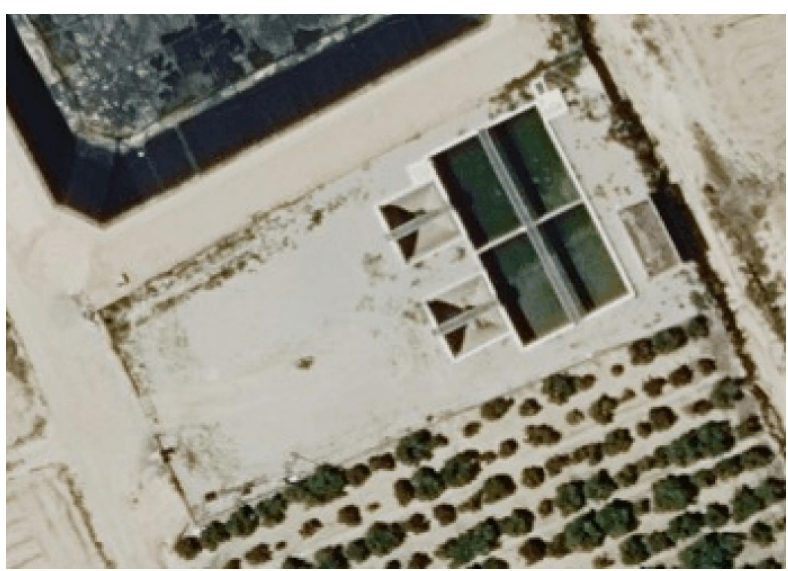

(b)

Figure 4. (a) Doña Pepa WWTP before its transformation; (b) Doña Pepa WWTP after transformation into a combined sewer system storm overflow tank. Source: (a) Google Earth (7 June 2018); (b) ICV (2021) (21 June 2021). Own elaboration.

Finally, the treated water is stored in a $1400 \mathrm{~m}^{3}$ tank at the Lo Pepín WWTP. This infrastructure enables improved water management for its reuse in irrigating parks and gardens and the La Marquesa golf course. From this tank, treated water is also pumped $2.6 \mathrm{~km}$ to the El Recorral Forest Park, which is the discharge point authorised by the River Segura Management Authority [44]. To meet the proposed objective of totally reusing the treated water from the Lo Pepín WWTP, five artificial ponds were built in the El Recorral Forest Park (Figure 5), and a new ecosystem was created thanks to the availability of this non-conventional water resource. 


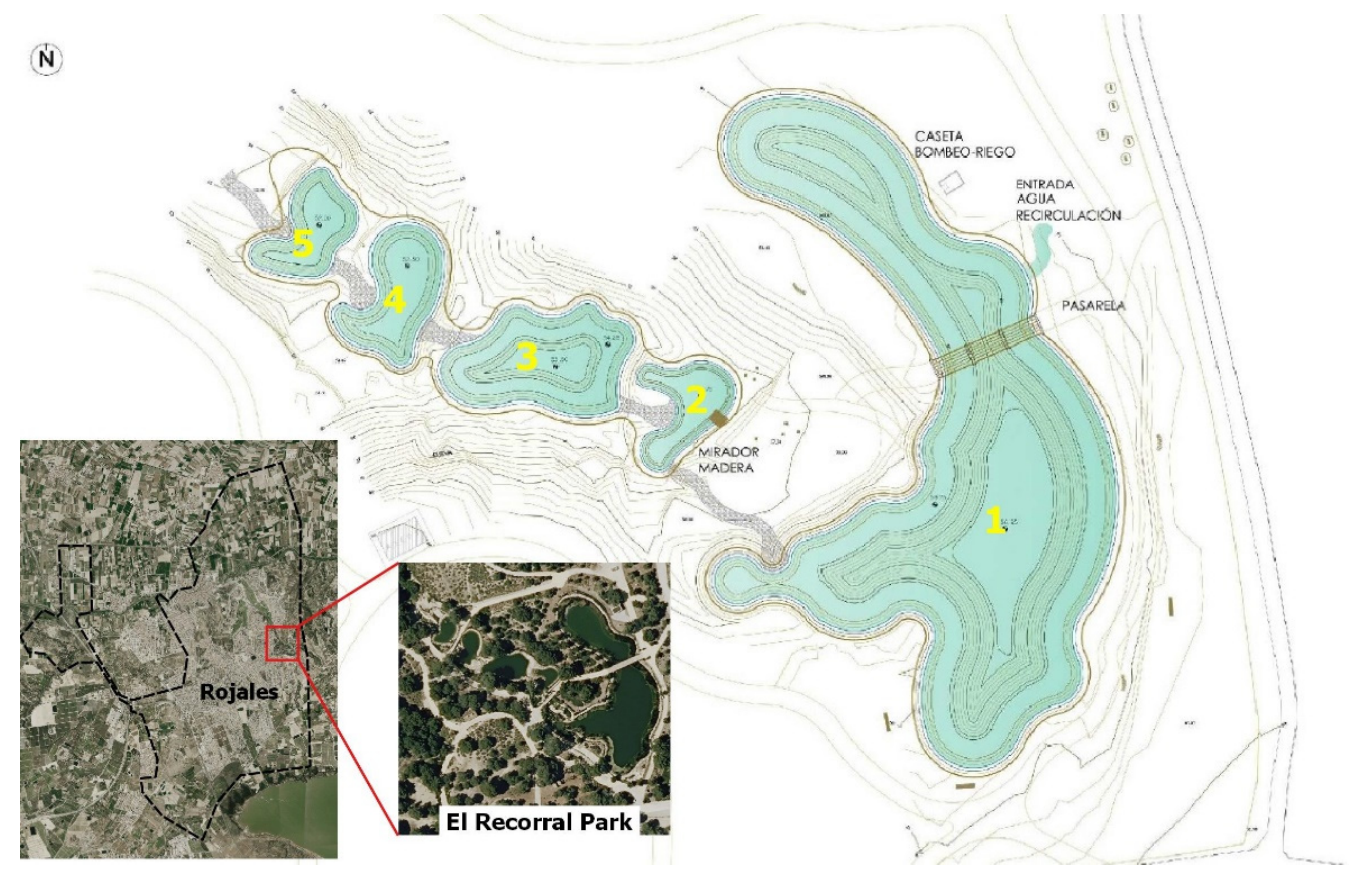

Figure 5. El Recorral Forest Park pond system. Key: (1) first pond $\left(4652 \mathrm{~m}^{3}\right)$, (2) second pond $\left(82 \mathrm{~m}^{3}\right)$, (3) third pond $\left(313 \mathrm{~m}^{3}\right)$, (4) fourth pond $\left(149 \mathrm{~m}^{3}\right)$, (5) fifth pond $\left(108 \mathrm{~m}^{3}\right)$. Source: Hidraqua Gestión Integral de Aguas de Levante S.A [44] and ICV (2021) (22 December 2021). Own elaboration.

This action was planned considering the profile of the land to integrate the ponds into the surroundings and receive the runoff water generated in the catchment area of the park. The slopes of the land were changed in some areas to encourage the retention of rainwater and its infiltration. To this end, the first and largest pond $\left(4652 \mathrm{~m}^{3}\right)$ is in the flattest area. In an adjacent valley, the following four ponds are arranged with volumes of 82, 313, 149 and $108 \mathrm{~m}^{3}$ respectively. These ponds descend through the Agustinillos ravine to where the discharge is authorised. The main function of this pond system is to receive the treated water and create a discharge point. In addition to the recreational and ornamental use of the water, there are other needs, such as the irrigation of the park's green areas and supplying the fire-fighting network with a volume of $107,245 \mathrm{~m}^{3}$ and $30,600 \mathrm{~m}^{3}$, respectively. The town council also uses $18,750 \mathrm{~m}^{3}$ of treated water for street cleaning. Therefore, the water provided to cover the demands of the Rojales Town Council is 163,000 $\mathrm{m}^{3}$ [44] (Table 2). The Recorral Forest Park is a clear example of a nature-basedsolution for managing rainwater runoff and using treated water. In this way, non-conventional water resources are reused and this increases the environmental and landscape value of the surroundings and stops years of uncontrolled dumping in the coastal wetlands of La Mata and Torrevieja.

\subsection{Daya Nueva}

The subject of the second case study is the municipality of Daya Nueva, where Hidraqua in collaboration with the town council, adapted an area of land for sustainable municipal use. The creation of the Europa Parque (Figure 6) was proposed for this means, with the objective of providing a green area alongside a new medical centre.

The urban centre of Daya Nueva, and specifically the site of the project, is mostly flat and this hindered the drainage of runoff that was once largely managed by the irrigation channels that dominated, and in part still dominates, the Bajo Segura area. In this case, it is important to highlight the presence, along the CV-901 road to the south of the Europa Parque, of the Almoradí Water Canal (Acequia Mayor de Almoradí), which is part of the rainwater management of systemin the area and so forms part of this measure. The Europa Park is a recreational green area with a potential drainage capacity by means of drainage pipes. 
Table 2. Reuse of treated water prior to the implementation of these measures.

\begin{tabular}{|c|c|}
\hline \multicolumn{2}{|c|}{ Treated Water in the Southern Basin of the Municipality of Rojales WWTP } \\
\hline \multicolumn{2}{|c|}{ Treated Water ( $\mathrm{m}^{3} /$ day) } \\
\hline Lo Pepín & 921 \\
\hline Doña Pepa & 223 \\
\hline Ciudad Quesada II & 85 \\
\hline Total (m³ /day) & 1229 \\
\hline Total (m³/year) & 448,585 \\
\hline \multicolumn{2}{|c|}{ USES (m³/year) } \\
\hline La Marquesa Golf Course & 275,000 \\
\hline Irrigation & 17,710 \\
\hline Irrigation Association & 23,395 \\
\hline Total & 320,395 \\
\hline Surplus treated water without reuse & 128,480 \\
\hline
\end{tabular}

Source: Hidraqua Gestión Integral de Aguas de Levante SA [44].

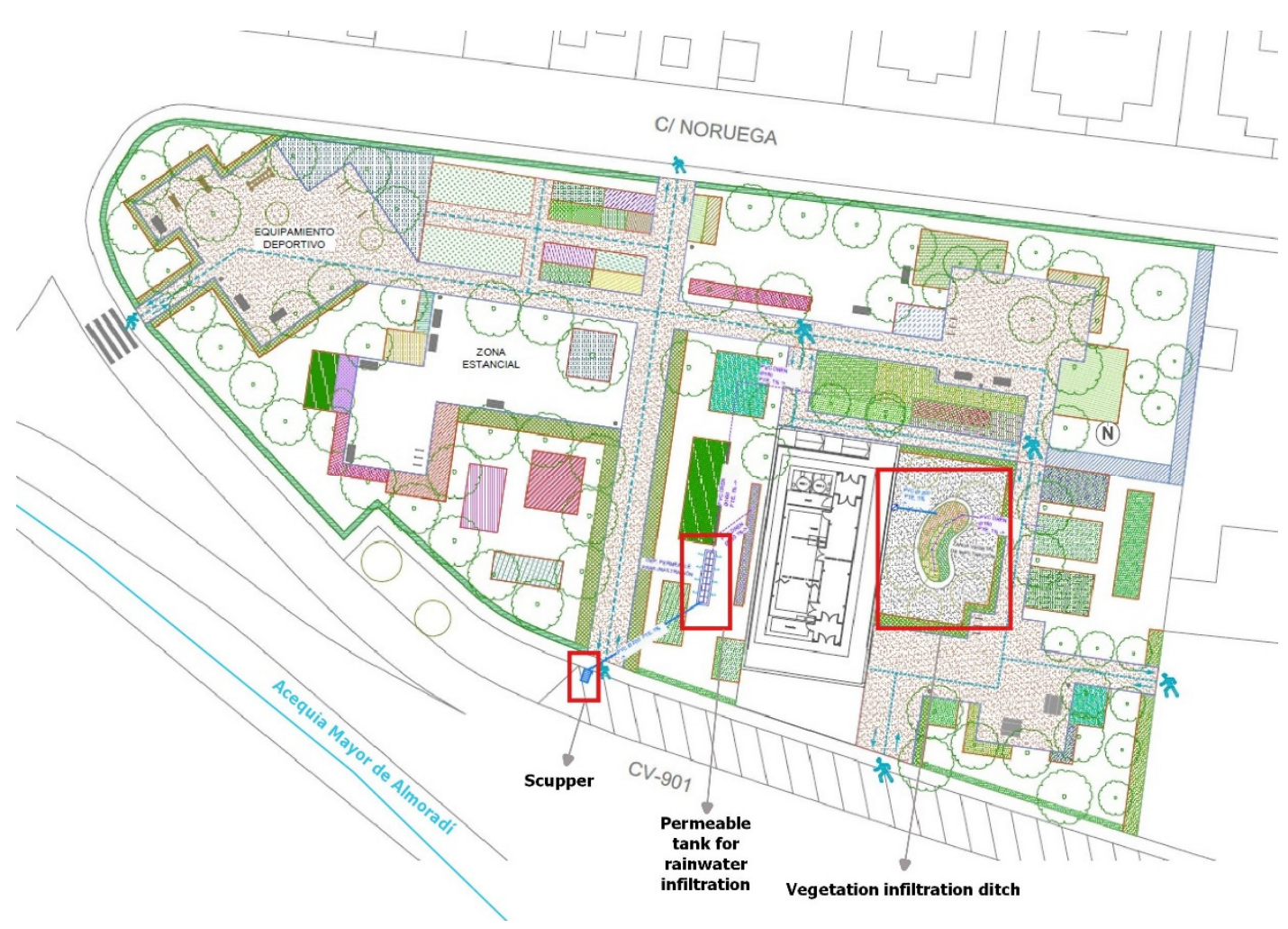

Figure 6. Location and design of the Europa Park in Daya Nueva. Source: Hidraqua Gestión Integral de Aguas de Levante S.A.

This project has consisted, firstly, of the construction of a SUDS, which aims to drain the runoff that flows into the park's basin. The main function of the vegetation infiltration ditch is to capture the rainwater flowing from the scupper and to encourage the infiltration of the filtered flows into the ground through drainage pipes. In the event of the filtration area collapsing, the water would be diverted from the scupper to the Acequia Mayor de Almoradí. During the installation of this infiltration ditch, the value of the permeability coefficient was calculated when designing the structure. A test was implemented at the reservoir site, according to a method described in the British publication BRE Digest 365, 
"Soakaway Design". The test consists in filling with water the excavation planned for the construction of the filtering structure and taking measurements of the change, in real time, of the water level until it has completely soaked away. Secondly, the permeable tank for rainwater infiltration located in front of the building receives rainwater from the building (a medical centre) through a drenotube (a micro-perforated drainage pipe covered with a geotextile and gravel to prevent the infiltration of fine sands). This enables rainwater falling on the roof of the building to infiltrate into the park's ground and so reduce the amount of runoff circulating on the asphalt.

\subsection{San Fulgencio}

The third case study corresponds to a floodable pond next to the San Fulgencio Municipal Sports Centre (Figure 7). The main aim of this project is to provide a green area that uses treated water from the San Fulgencio-Dayas WWTP.

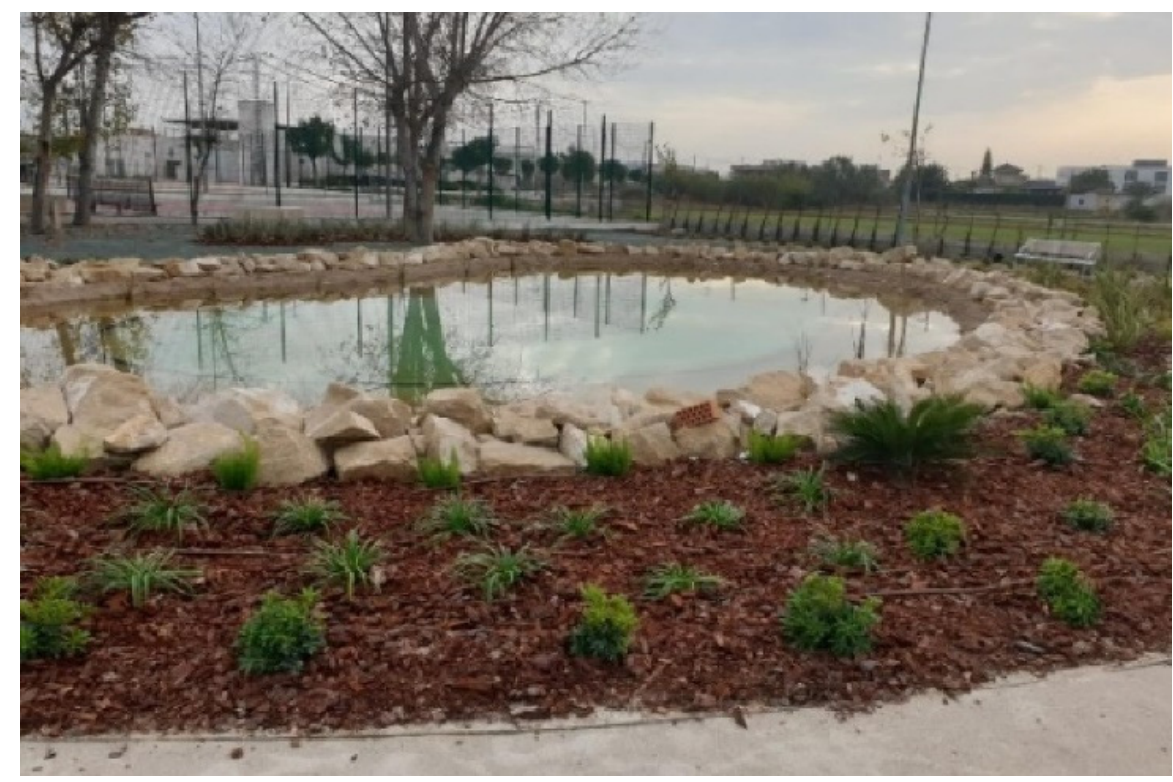

Figure 7. Floodable pond. Source: García de Consuegra Priego [39] (p. 582).

This way the municipal plan for the use of water from the wastewater treatment plant is continued, which was jointly initiated by the San Fulgencio Town Council and Hidraqua in 2017. Previously, the $800,000 \mathrm{~m}^{3}$ of water regenerated in the treatment plant was discharged into the sea. From this point onwards, treated wastewater in the municipality of San Fulgencio has been used for irrigation [47]. However, with the construction of the floodable pond, the amount of green areas are increased, the use of treated water is encouraged for its ornamental function and use in irrigation of the vegetation to avoid the discharge into the sea of this non-conventional water resource. It is necessary to consider that the existence of this action enables this environment to adapt and adequately manage runoff in the area. This pond is equipped with a remote-control system that regulates the water level-and the level is reduced during rainy weather to capture the runoff. In addition, the pond is surrounded by bioretention vegetation ditches with a layer of geotextile to filter out the heavier materials diluted in the water. These ditches are designed to capture runoff water generated on the surface and so favour its retention in the place of origin. Both the scuppers and filtering ditches capture the surface runoff generated, filter it and transport it through drainage pipes to the overflow chamber that discharges the water into the ditch network.

\section{Discussion}

The increase in intense rainstorms and sealed surfaces due to excessive urbanisation has led to an increase in urban areas affected by flooding. In consequence, a change in thinking is taking place in terms of addressing this problem with the implementation 
of NBS and SUDS. However, rainwater must be considered as a potential resource that, through these alternative systems, enables the creation and maintenance of green areas and reduces the use of conventional water resources for these means. Rainwater and treated water are becoming increasingly important in the urban water cycle, as it is possible solution to improve the quality of water using physical and biological filters before being purified and regenerated.

The local scale is ideal for developing measures of adaption to climate change [25]. Hence, in recent years, local initiatives around the world have mitigated the effects of global warming. This is the case of cities such as Copenhagen, Rotterdam, Tokyo, Nagoya, Helsinki, London, Sydney, Chicago, and New York [7,48,49]. These actions include the implementation of urban drainage systems based on the construction of high-capacity collectors and SUDS, as well as comprehensive territorial planning measures.

American cities such as Detroit, Denver, and Lancaster (Pennsylvania) offer good examples of the implementation of SUDS as measures of adaptation to climate change. Another example of sustainable urban planning against the effects of climate change on temperatures and rainfall is the implementation of "green roofs" (found, for example, in Copenhagen or Antwerp) [25]. Munich has developed a plan to adapt to climate change through the creation of green spaces and urban drainage actions to reduce the risk of flooding from the Isar River [50]. For its part, the programme of adaptation to climate change in the city of Rotterdam is of great interest for the integrated conception of the phenomenon (sea level rise, marine intrusion, increase of flood events, increase in the island of urban heat, and climate discomfort) and the response (structural measures and territorial planning) [51].

Another outstanding experience of adaptation to changes in rainfall due to climate change has been developed in the Baltic Sea region. The BaltCica project (Climate Change in Baltic Sea Region) has culminated with the approval of municipal ordinances for carrying out measures to adapt to climate change and include "green" rainwater collection systems. Other relevant initiatives have been developed in Wales (Pumlumon area), Flanders (Schelde basin), and Augustenborg (Sweden). In all these cases, territorial planning based on the treatment of green infrastructure has been decisive for the subsequent design of actions to adapt to climate change, especially extreme rainfalls and its effects on urban areas. The analysis carried out in this study highlights the measures implemented in the municipalities of Rojales, Daya Nueva, and San Fulgencio, pioneers in these types of projects in the Bajo Segura. These systems, although planned within a sustainable framework of integrated water management, present small deficiencies related with the structural nature of the measures. The case of Rojales stands out for its size and capacity of adaptation of a highly modified territory. The infrastructure developed in the El Recorral Forest Park, completed in May 2019, has transformed this space into a recreational and ornamental area, that also helps manage the water cycle, mitigates flood risk and uses non-conventional water resources. Such water reuse has been made possible following the remodelling of the Lo Pepín WWTP and the Doña Pepa combined sewer system storm overflow tank, completed in November 2019 and January 2021, respectively. The work conducted in November 2020 in the Europa Park in Daya Nueva shows a sustainable approach to runoff management, with drainage systems using filtering ditches to control the quality of runoff at source and help ground infiltration. The San Fulgencio floodable pond, completed in December 2019, enables the management of runoff in the area despite the steepness of the terrain. These initiatives, planned on a local scale, are the result of the work conducted by the local administrations and Hidraqua. The town councils are responsible for approving these projects and granting the building permits. There is close collaboration between the municipal councils and the water concessionary company that developed the infrastructures. These actions have proven effective in mitigating the effects of runoff on a local scale and are working as planned. These works were mostly completed after the rainstorm of 2019 affected the area around El Recorral Park. 
Other methods for managing urban runoff are used in various locations along the Mediterranean coast. The best-known actions in the province of Alicante are the Parque Inundable de La Marjal and the Tanque Anticontaminación Ingeniero José Manuel Obrero Díez, as studied and analysed by Hernández et al. [52], Morote Seguido and Hernández [28,29] and Olcina Cantos et al. [7]. These authors highlight the importance of this type of action as it increases the supply of water for certain uses, reduces the use of drinking water, improves flood risk management and reduces the pollutant runoff load.

Along the same lines, Casal-Campos et al. [53], Perales Momparler [54] and PeralesMomparler et al. [16,32,54] focus on the province of Valencia, where they analyse sustainable drainage actions in the towns of Xàtiva and Benaguasil and endorse the implementation of SUDS as a flexible measure for the management of urban runoff, as well as mitigation and adaptation to climate change. For the efficient management of urban runoff, it is vitally important to consider the factor of pollution on sealed surfaces. Andrés-Doménech et al. [31] have studied the quantity and quality of runoff at the campus of the Universitat Politècnica de València, at the same time as evaluating the influence of the weather on the washing away of pollutants by urban runoff.

In the case of the city of Palma de Mallorca, the recurrence of flooding due to uncontrolled urban sprawl and the deficiency of the rainwater management system, as it is a unitary system, has highlighted the need to implement measures that enable better management of runoff water. The local administration has developed a green plan, which includes the development of parks with highly permeable areas (green wedges) to reduce the impact of flooding in the city. In addition, a rainwater tank is under construction to the east of the city, which is expected to be completed by 2022 [55]. Rainwater is therefore being turned into a potential source for the urban water cycle. According to a study conducted by Domènech and Vallès [56], rainwater is used as an alternative source in the metropolitan region of Barcelona, where various ordinances since 2002 have required water saving through the installation of rainwater collectors or greywater reuse systems in new buildings [56]. Domènech and Saurí study a paradigmatic case in the municipality of Sant Cugat del Vallès [57], where this type of water resource has been incorporated into the social water cycle as part of the implementation of a municipal plan for adaptation to climate change. In this sense, the potential use of rainwater in the Mediterranean region is becoming increasingly important, and studies conducted by Villar-Navascués et al. [58,59] for the province of Alicante propose rainwater harvesting for domestic consumption as an alternative to conventional resources and as a measure for adapting to climate change.

The implementation of the Vega Renhace Plan [38] for the improvement of resilience in the Vega Baja del Segura area (which is affected by extreme weather events-mainly floods and droughts) could offer an important boost for the development of municipal measures for the use of rainwater. This strategic plan includes 28 priority actions to be developed in the coming years for the socio-economic recovery of this territory and adaptation to extreme weather. These measures include: (a) the renovation of all the area's WWTPs (tertiary systems and desalination) to achieve 100\% wastewater reuse (action number 10) in one of the areas most affected by drought in the dry climatic region of the southeast Iberian Peninsula; and (b) the implementation of sustainable urban drainage systems in municipalities, under the formula of public-private cooperation with the drinking water concessionary companies. In this sense, the Vega Baja RenHace Plan includes hard and soft sustainability measures for 18 of the 27 municipalities in the Bajo Segura area.

\section{Conclusions}

This research presents a general analysis of the regenerated rainwater and wastewater measures implemented in the municipalities of the Bajo Segura. This analysis justifies the use of these measures, which have encouraged the creation of new green areas, increased new permeable surfaces, while lowering the risk of flooding by reducing the volumes accumulating during heavy rainstorms. 
The three actions described above have been beneficial. In the case of Rojales the supply of treated wastewater for urban uses was increased by $163,000 \mathrm{~m}^{3}$. The treated flow is now fully reused and so discharges to the salt lagoons of La Mata and Torrevieja have ended. In Daya Nueva, sustainable drainage is a priority for managing runoff at source and favouring ground infiltration; while in San Fulgencio, the pond, in addition to receiving treated water, manages the local runoff and discharges filtered water into a network of irrigation canals.

In this respect, the interest shown by Hidraqua Gestión Integral de Aguas de Levante SA (part of the Suez Group), the concessionary for environmental services and integral water cycle, must be highlighted. These actions show that the company is pursuing sustainable development objectives to create more resilient cities that can adapt to climate change. Under the principle of social responsibility within the framework of integrated water management, the company is committed to water-efficient alternatives that favour water reuse, while improving the management of urban runoff in problematic areas. The resulting green areas create biodiversity and cushion the effects of runoff by reducing its quantity and improving its quality - and treated wastewater replaces drinking water for ornamental purposes and irrigation.

Interest in rainwater management has increased in recent decades as it has been considered a valuable resource within the water cycle. In view of this, NBS and SUDS are being consolidated as tools for dealing with rainwater management by reducing circulating runoff and enhancing water quality. Although these actions have multiple benefits, the cost of the infrastructures is one of the factors that makes it difficult to implement at a local level. Therefore, it is necessary to incorporate these systems into territorial planning and provide development aid and subsidies [25]. It is also necessary to implement Municipal Climate Change Adaptation Plans, which call for the fulfilment of Goal 6 on Clean Water and Sanitation and Goal 13 on Climate Action as proposed in the 2030 Agenda for the achievement of the sustainable development goals.

The implementation of sustainable measures for runoff water management is acquiring significant importance in the integral water cycle, as these measures represent an adaptation to the effects of floods and drought by contributing to the creation of more resilient cities. Given the limited scientific evidence on the operation of these systems in south-eastern Spain, the dissemination of these experiences is essential. These solutions enable the social challenges of the 21st century to be faced but require social responsibility for their maintenance and effectiveness [60]. Although we have been given access to the technical projects plans of the measures described, in some cases, the publication of their content is not allowed, which limits the provision of more information and the descriptive richness of any research. The measures described in this article should be evaluated in the future to determine their effectiveness. Other infrastructures already planned or executed within the framework of the Vega Baja RenHace Plan should also be described, together with an analysis of the results of the European B-WaterSmart project for the province of Alicante.

As far as future lines of research are concerned, work is being carried out on the statistical analysis of the evolution of extreme rainfall in the province of Alicante, which will allow us to better understand the influence that climate change is having on the precipitation regime so that we can create more resilient cities. Various authors [61,62] consider the possibility of applying remote sensing techniques to evaluate precipitation, obtain hourly climate variables and analyse changes in extreme rainfall so as to better predict the future intensification of floods and boost resilience to climate change.

Author Contributions: Conceptualization, Methodology, Formal Analysis, and Investigation, E.S.-A., J.O.-C. and J.M.-T. All authors have read and agreed to the published version of the manuscript.

Funding: This research was funded by Generalitat Valenciana, within the project "Climate change and water: non-conventional resources as an adaptive strategy to increase the resilience of agricultural and urban-tourist uses on the Alicante coastline", grant number AICO/2020/253; by the Vice-Rectorate for Research of the University of Alicante (predoctoral fellowship to E.S.-A., reference FPUA2019-54). 
Institutional Review Board Statement: Not applicable.

Informed Consent Statement: Not applicable.

Data Availability Statement: Not applicable.

Acknowledgments: The authors would like to thank the specialists of the company Hidraqua Gestión Integral de Aguas de Levante SA. for the information provided. We would also like to thank the specialists at the Rojales Town Council for the information provided and their attention.

Conflicts of Interest: The authors declare no conflict of interest.

\section{References}

1. Intergovernmental Panel on Climate Change (IPCC). Cambio Climático 2014: Informe de Síntesis. Contribución de los Grupos de Trabajo I, II y III al Quinto Informe de Evaluación del Grupo Intergubernamental de Expertos Sobre el Cambio; IPCC: Ginebra, Switzerland, 2014.

2. Intergovernmental Panel on Climate Change (IPCC). Global Warming of $1.5^{\circ} \mathrm{C}-\mathrm{An}$ IPCC Special Report on the Impacts of Global Warming of $1.5^{\circ} \mathrm{C}$ Above Pre-Industrial Levels and Related Global Greenhouse Gas Emission Pathways, in the Context of Strengthening the Global Response to the Threat of Climate Change; IPCC: París, France, 2018.

3. Intergovernmental Panel on Climate Change (IPCC). Climate Change and Land: An IPCC Special Report on Climate Change, Desertification, Land Degradation, Sustainable Land Management, Food Security, and Greenhouse Gas Fluxes in Terrestrial Ecosystems; IPCC: Geneva, Switzerland, 2019.

4. Olcina Cantos, J. Incremento de episodios de inundación por lluvias de intensidad horaria en el sector central del litoral Mediterráneo Español: Análisis de tendencias en Alicante. Sémata: Cienc. Sociais Humanid. 2017, 29, 143-163. [CrossRef]

5. Olcina Cantos, J.; Biener Camacho, S. Evidencias del proceso de calentamiento térmico planetario en el litoral mediterráneo español. In Spanish Contribution to 34th IGC. Istanbul 2020 Spanish Committee of the International Geographical Union. Spain, Bridge between Continents, 1st ed.; Comité Español de la Unión Geográfica Internacional (UGI); Centro Nacional de Información Geográfica: Madrid, Spain, 2020; pp. 155-166. [CrossRef]

6. Olcina Cantos, J.; Vera-Rebollo, J.F. Adaptación del sector turístico al cambio climático en España. La importancia de las acciones a escala local y en empresas turísticas. An. Geogr. Univ. Complut. 2016, 36, 321-352. [CrossRef]

7. Olcina Cantos, J.; Campos Rosique, A.; Casals del Busto, I.; Ayanz López-Cuervo, J.; Rodríguez Mateos, M.; Martínez Puentes, M. Resiliencia en el ciclo urbano del agua. Extremos pluviométricos y adaptación al cambio climático en el ámbito Mediterráneo. Aquae Pap. 2018, 8, 1-193. Available online: http:/ / rua.ua.es/dspace/handle/10045/76370 (accessed on 30 November 2021).

8. Eckstein, D.; Künzel, V.; Schäfer, L. Global Climate Risk Index 2021. Who Suffers Most from Extreme Weather Events? Weather-Related Loss Events in 2019 and 2000 to 2019; Germanwatch: Berlin, Germany, 2021; p. 49. Available online: https:/ / germanwatch.org/es/ 19777 (accessed on 14 October 2021).

9. Shen, G.; Hwang, S.N. Spatial-Temporal snapshots of global natural disaster impacts Revealed from EM-DAT for 1900-2015. Geomat. Nat. Hazards Risk 2019, 10, 912-934. [CrossRef]

10. Pérez Morales, A.; Gil Guirado, S.; Olcina Cantos, J. Housing bubbles and the increase of flood exposure. Failures in flood risk management on the Spanish south-eastern coast (1975-2013). Flood Risk Manag. 2015, 11, 1-12. [CrossRef]

11. Olcina Cantos, J.; Hernández Hernández, M.; Rico Amorós, A.M.; Martínez Ibarra, E. Increased risk of flooding on the coast of Alicante (Region of Valencia, Spain). Nat. Hazards Earth Syst. Sci. 2010, 10, 2229-2234. [CrossRef]

12. Gil-Guirado, S.; Pérez-Morales, A.; López-Martínez, F. SMC-Flood database: A high-resolution press database on flood cases for the Spanish Mediterranean coast (1960-2015). Nat. Hazards Earth Syst. Sci. 2019, 19, 1955-1971. [CrossRef]

13. European Spatial Planning Observation Network (ESPON). The Spatial Effects and Management of Natural and Technological Hazards in Europe. 2006. Available online: https:/ /www.espon.eu/sites/default/files/attachments/Final\%20Report\%20Main\% 20Report.pdf (accessed on 17 November 2021).

14. Jato-Espino, D.; Sillanpää, N.; Andrés-Doménech, I.; Rodriguez-Hernandez, J. Flood risk assessment in urban catchments using multiple regression analysis. J. Water Resour. Plan. Manag. 2018, 144, 04017085. [CrossRef]

15. Woods-Ballard, B.; Wilson, S.; Udale-Clarke, H.; Illman, S.; Scott, T.; Ashley, R.; Kellagher, R. The SuDS Manual, 5th ed.; CIRIA: London, UK, 2015.

16. Perales-Momparler, S.; Andrés-Doménech, I.; Hernández-Crespo, C.; Vallés-Morán, F.; Martín, M.; Escuder-Bueno, I.; Andreu, J. The role of monitoring sustainable drainage systems for promoting transition towards regenerative urban built environments: A case study in the Valencian region, Spain. J. Clean. Prod. 2017, 163, S113-S124. [CrossRef]

17. Eguibar, M.Á.; Porta-García, R.; Torrijo, F.J.; Garzón-Roca, J. Flood Hazards in Flat Coastal Areas of the Eastern Iberian Peninsula: A Case Study in Oliva (Valencia, Spain). Water 2021, 13, 2975. [CrossRef]

18. Fundación Nueva Cultura del Agua (FNCA). Fundación Nueva Cultura del Agua. Available online: https://fnca.eu/en/ (accessed on 2 July 2021).

19. European Communities. Directive 2000/60/EC of the European Parliament and of the Council of 23 October 2000 establishing a framework for Community action in the field of water policy. Off. J. Eur. Communities 2000, 43, 1-75. Available online: http:/ / data.europa.eu/eli/dir/2000/60/oj (accessed on 1 April 2021). 
20. Castro-Fresno, D.; Andrés-Valeri, V.C.; Sañudo-Fontaneda, L.A.; Rodriguez-Hernandez, J. Sustainable drainage practices in Spain, specially focused on pervious pavements. Water 2013, 5, 67-93. [CrossRef]

21. España. Ministerio de la Presidencia. Real Decreto 903/2010, de 9 de Julio, de Evaluación y Gestión de Riesgos de Inundación. Boletín Estado 2010, 171, 61954-61967. Available online: https:/ /www.boe.es/eli/es/rd/2010/07/09/903 (accessed on 1 April 2021).

22. España. Ministerio de Agricultura y Pesca, A. y M. A. Real Decreto 638/2016, de 9 de diciembre, por el que se modifica el Reglamento del Dominio Público Hidráulico aprobado por el Real Decreto 849/1986, de 11 de abril, el Reglamento de Planificación Hidrológica, aprobado por el Real Decreto 907/2007, de 6 de. Boletín Estado 2016, 314, 91133-91175.

23. de Agricultura, M.; Ambiente, A.Y.M. Manual Nacional de Recomendaciones para el Diseño de Tanques de Tormenta; MAGRAMA: Madrid, Spain, 2014. Available online: https://www.aeas.es/images/publicaciones/manuales/Manual_Tanques_Tormenta_ MAGRAMA.pdf (accessed on 27 March 2021).

24. Pérez Zabaleta, A.; Gracia de Rentería, P.; Ballestero Olza, M.; Pérez Foguet, A.; Ezbakhe, F.; Guerra-Librero Castilla, A. Análisis de las Necesidades de Inversión en Renovación de las Infraestructuras del Ciclo Urbano del Agua, 1st ed.; Universidad Nacional de Educación a Distancia (UNED) y Fundación Aguae: Madrid, Spain, 2019. [CrossRef]

25. Arahuetes, A.; Olcina Cantos, J. The potential of sustainable urban drainage systems (SuDS) as an adaptive strategy to climate change in the Spanish Mediterranean. Int. J. Environ. Stud. 2019, 76, 764-779. [CrossRef]

26. Fernández Rodríguez, H.; Trapote Jaume, A.; Fernández Mejuto, M. Sistemas Urbanos de Drenaje Sostenible. Tipos y objetivos. In Riesgo de inundación en España: Análisis y Soluciones para la Generación de Territorios Resilientes, 1st ed.; López Ortiz, M.I., Melgarejo Moreno, J., Eds.; Alicante, Universidad de Alicante: Orihuela, Spain, 2020; pp. 773-786.

27. Fresno, D.C.; Bayón, J.R.; Hernández, J.R.; Muñoz, F.B. Sistemas Urbanos de Drenaje Sostenible (SUDS). Interciencia 2005, 30 , 1-25. Available online: http:/ / www.redalyc.org/articulo.oa?id=33910403 (accessed on 30 November 2021).

28. Morote Seguido, Á.F.; Hernández Hernández, M. El uso de aguas pluviales y de tormenta en la ciudad de Alicante. De riesgo a recurso hídrico alternativo. In XV Coloquio Ibérico de Geografía. Retos y tendencias de la Geografía Ibérica. Murcia, España, 7-9 Novimebre 2016; García Marín, R., Alonso Sarría, F., Belmonte Serrato, F., Moreno Muñoz, D., Eds.; Universidad de Murcia y Asociación de Geógrafos Españoles: Murcia, Spain, 2016; pp. 1008-1015.

29. Morote Seguido, Á.F.; Hernández Hernández, M. El uso de aguas pluviales en la ciudad de Alicante. De viejas ideas a nuevos enfoques. Pap. Geogr. 2017, 1, 7-25. [CrossRef]

30. Perales Momparler, S. Sistemas Urbanos de Drenaje Sostenible (SUDS)—Expo Zaragoza 2008—Agua Y Serv—De Abastecimiento Y Saneam. 2008. Available online: http://www.zaragoza.mobi/contenidos/medioambiente/cajaAzul/33S8-P3-SaraPeralesACC. pdf (accessed on 28 March 2021).

31. Andrés-Doménech, I.; Hernández-Crespo, C.; Martín, M.; Andrés-Valeri, V.C. Characterization of wash-off from urban impervious surfaces and SuDS design criteria for source control under semi-arid conditions. Sci. Total Environ. 2018, 612, 1320-1328. [CrossRef] [PubMed]

32. Perales-Momparler, S.; Hernández-Crespo, C.; Vallés-Morán, F.; Martín, M.; Andrés-Doménech, I.; Andreu Álvarez, J.; Jefferies, C. SuDS efficiency during the start-up period under Mediterranean climatic conditions. Clean Soil Air Water 2014, 42, 178-186. [CrossRef]

33. Perales Momparler, S.; Andrés-Doménech, I. Los sistemas urbanos de drenaje sostenible: Una alternativa a la gestión del agua de lluvia. Retema Rev. Técnica Medio Ambiente 2008, 21, 92-104.

34. Trapote Jaume, A. Influencia de los Sistemas Urbanos de Drenaje Sostenible (SUDS) en el diseño de colectores y en el riesgo de inundación. In Riesgo de Inundación en España: Análisis y Soluciones para la Generación de Territorios Resilientes, 1st ed.; López Ortiz M.I., Melgarejo Moreno, J., Eds.; Universidad de Alicante: Orihuela, Spain, 2020; pp. 787-797.

35. Perales, S.; Andrés, I.; Escalante, E.; Los Sistemas Urbanos de Drenaje Sostenible (SUDS) en la Hidrogeología urbana. IX Simposio de Hidrogeología; AEH-IGME: Elche, Spain, 2008; pp. 1-12. Available online: https://www.researchgate.net/publication/265057 760_Los_sistemas_urbanos_de_drenaje_sostenible_SUDS_en_la_hidrogeologia_urbana (accessed on 27 March 2021).

36. Soto-Fernández, R.; Perales-Momparler, S. El camino del agua en el paisaje urbano, barrio de Bon Pastor, Barcelona. In Proceedings of the V Water Engineering Conference, A Coruña, Spain, 24-26 October 2017; pp. 1-9.

37. Andrés-Doménech, I. Una apuesta decidida por el drenaje urbano sostenible. El Econ. 2017, 46, $20-21$.

38. Generalitat Valenciana. Plan Vega Renhace. Una Estrategia Integral para la Resiliencia de la Comarca de la Vega Baja del Segura; Generalitat Valenciana: Valencia, Spain, 2020. Available online: http://www.presidencia.gva.es/es/web/vega-renhace (accessed on 1 April 2021).

39. García de Consuegra Priego, M.E. Experiencias y propuestas para aumentar la resiliencia urbana frente a inundaciones. In Riesgo de Inundación en España: Análisis y Soluciones para la Generación de Territorios Resilientes; López Ortiz, M.I., Melgarejo Moreno, J., Eds.; Universidad de Alicante: Orihuela, Spain, 2020; pp. 569-589. Available online: http://hdl.handle.net/10045/109017 (accessed on 30 November 2021).

40. KWR. B-WaterSmart European Project. European Commision, Horizon 2020. 2021. Available online: https://www.kwrwater.nl/ en/projecten/b-watersmart/ (accessed on 14 November 2021).

41. Instituto Geográfico Nacional (IGN). Nomenclátor Geográfico de Municipios y Entidades de Población. Available online: http:/ / centrodedescargas.cnig.es /CentroDescargas / catalogo.do?Serie=NGMEN (accessed on 20 December 2021).

42. Morote, Á.F.; Hernández, M. Población extranjera y turismo residencial en el litoral de Alicante (1960-2011): Repercusiones territoriales. Eure 2016, 42, 55-76. [CrossRef] 
43. Ministerio de Hacienda y Función Pública. Portal de la Dirección General de Catastro: Estadísticas Catastrales. Catastro Inmobiliario Urbano. Available online: http:/ / www.catastro.minhap.gob.es/esp/estadistica_2.asp (accessed on 20 December 2021).

44. Hidraqua Gestión Integral de Aguas de Levante, S.A. Proyecto Básico para la Reutilización y Autorización de Vertido del Agua Depurada en la Cuenca sur del T.M. de Rojales; Hidraqua y Ayuntamiento de Rojales: Rojales, Spain, 2016; p. 111.

45. Ministerio de Medio Ambiente. RESOLUCIÓN de 25 de mayo de 1998, de la Secretaría de Estado de Aguas y Costas, por la que se declaran las «zona sensible» en las cuencas hidrográficas intercomunitarias. Boletín Estado 1998, 155, 34635-34636.

46. Gobierno de España. Ministerio de la Presidencia. Real Decreto 1620/2007, de 7 de diciembre, por el que se establece el régimen jurídico de la reutilización de las aguas depuradas. Boletín Estado 2007, 294, 50639-50661.

47. Diario Información. San Fulgencio Regará con Agua Regenerada. 2017. Available online: https://www.informacion.es/vegabaja/2017/09/26/san-fulgencio-regara-agua-regenerada-5879270.html (accessed on 13 January 2021).

48. De Graaf, R.; Van der Brugge, F. Transforming water infrastructure by linking water management and urban renewal in Rotterdam. Technol. Forecast. Soc. Change 2010, 77, 1282-1291. [CrossRef]

49. Olcina, J.; Vera, J.F. Climate change and tourism policy in Spain: Giagnosis in the Spanish Mediterranean. Cuad. Tur. 2016, 38, 565-571. [CrossRef]

50. Olcina, J.; Miró Pérez, J.J. Actividad Turística y Cambio Climático en la Comunidad Valenciana; Universidad de Alicante: Alicante, Spain; Instituto Universitario de Investigaciones Turísticas: Alicante, Spain; Agència Valenciana del Turisme: Valencia, Spain, 2017 ; p. 130.

51. Amelung, B. The Rotterdam Climate Change Adaptarion Strategy. In Cambio Climático en el Mediterráneo. Procesos, Riesgos y Politicas, 1st ed.; Romero, J., Olcina, J., Eds.; Tirant Humanidades: Valencia, Spain, 2021; pp. 303-309.

52. Hernández Hernández, M.; Saurí Pujol, D.; Moltó Mantero, E. Las aguas pluviales y de tormenta: Del abandono de un recurso hídrico con finalidad agrícola a su implantación como recurso no convencional en ámbitos urbanos. In Paisaje, Cultura Territorial y Vivencia de la Geografía. Libro Homenaje al Profesor Alfredo Morales Gil, 1st ed.; Vera, J.F., Olcina Cantos, J., Hernández, M., Eds.; Alicante, Servicio de Publicaciones de la Universidad de Alicante: Alicante, Spain, 2016; pp. 1099-1120. [CrossRef]

53. Casal-Campos, A.; Jefferies, C.; Perales Momparler, S. Selecting SUDS in the Valencia Region of Spain. Water Pract. Technol. 2012, 7, 1. [CrossRef]

54. Perales Momparler, C.S. A Regenerative Urban Stormwater Management Methodology. The Role of SUDS Construction and Monitoring. In the Transition of a Mediterranean City. Ph.D. Thesis, Universitat Politècnica de València, Valencia, Spain, 2015.

55. Rosselló-Geli, J.; Grimalt-Gelabert, M. Mapping of the Flood Distribution in an Urban Environment: The Case of Palma (Mallorca, Spain) in the First Two Decades of the 21st Century. Earth 2021, 2, 960-971. [CrossRef]

56. Domènech, L.; Vallès, M. Local regulations on alternative water sources: Greywater and rainwater use in the Metropolitan Region of Barcelona. Investig. Geográficas 2014, 61, 87-96. [CrossRef]

57. Domènech, L.; Saurí, D. A comparative appraisal of the use of rainwater harvesting in single and multi-family buildings of the Metropolitan Area of Barcelona (Spain): Social experience, drinking water savings and economic costs. J. Clean. Prod. 2011, 19, 598-608. [CrossRef]

58. Villar-Navascués, R.; Pérez-Morales, A.; Gil-Guirado, S. Evaluación del potencial de captación de aguas pluviales en tejados en Alicante. In Tecnologías de la Información Geográfica: Perspectivas Multidisciplinares en la Sociedad del Conocimiento, 1st ed.; López García, M.J., Carmona, P., Saom, J., Albertos, J.M., Eds.; Valencia, Universidad de València: Valencia, Spain, 2018 ; pp. $433-443$.

59. Villar Navascués, R.; Pérez Morales, A.; Gil Guirado, S. Assessment of rainwater harvesting potential from roof catchments through clustering analysis. Water 2020, 12, 2623. [CrossRef]

60. European Commission. Towards an EU Research and Innovation Policy Agenda for Nature-Based Solutions and Re-Naturing Cities. Final Report of the Horizon 2020 Expert Group on Nature-Based Solutions and Re-Naturing Cities (Fill Version); European Commission: Brussels, Belgium, 2015. [CrossRef]

61. Yin, J.; Gou, S.; Gu, L.; Zeng, Z.; Liu, D.; Chen, J.; Shen, Y.; Xu, C. Does the Hook Structure Constrain Future Flood Intensification Under Anthropogenic Climate Warming? Water Resour. Res. 2021, 57, 125878. [CrossRef]

62. Yin, J.; Guo, S.; Gentine, P.; Sullivan, S.C.; Gu, L.; He, S.; Chen, J.; Liu, P. Blending multi-satellite, atmospheric reanalysis and gauge precipitation products to facilitate hydrological modelling. J. Hydrol. 2021, 593, 125878. [CrossRef] 